San Jose State University

From the SelectedWorks of Matthew Spangler

September, 2012

\title{
Review: Irish Culture and Colonial Modernity, 1800-2000: The Transformation of Oral Space
}

Matthew Spangler, San Jose State University 
on disability, Colleen Glenney Boggs on animal studies and affect theory, Paul Gilmore on cognitive science and embodiment). But it is a testament to the strength of this collection that these interventions rarely feel forced and that the volume-despite its title of Handbook-does not make a mission of covering its bases. What is stressed time and again, and to wonderful effect, is a flexible analytic pliability (rather than a single deterministic approach) that allows familiar texts to be experienced in new ways.

In the end, the most notable thing about The Oxford Handbook of Nineteenth-Century American Literature is its consistency. Anthologies are a famously uneven affair, with the occasional treasure often sandwiched between the unreadable and the mystifying. But in this carefully edited collection, there is not a single lemon, a remarkable achievement for a 443-page, 24-contributor volume. It will make for happy and durable reading for anyone interested in the dynamic new directions of nineteenth-century American literary studies.

Gillian Silverman University of Colorado, Denver

David Lloyd, Irish Culture and Colonial Modernity, 1800-2000: The Transformation of Oral Space. Cambridge: Cambridge University Press, 2011. Pp. x + 285. \$94.

If you go to YouTube and search the word "Irish," among the links that appear (at least when I did it on 25 September 2012) are: "How To Do An Irish Accent," "Shite Irish Girls Say," "Shite Irish Lads Say," "Traditional Irish Blessing," "What if the Beatles Were Irish," "What Shall We Do with the Drunken Sailor," "There's No One as Irish as Barack O'Bama," "An Irish Pub Song," "An Irish Drinking Song," and "Another Irish Drinking Song," followed by three more videos labeled "Irish Drinking Song." Aside from offering a litany of Irish stereotypes, what is striking about this list is how many of these videos feature the mouth in various acts of orality: singing, drinking, blessing, hyperbolizing, storytelling. Perhaps this should come as no surprise; it is YouTube, after all, and the videos favor spoken and musical performance. Even so, in this admittedly unscientific study, it seems that the mouth appears more frequently and notably in the returns for the search term "Irish" than for most other searches based on national identity. 
I offer this by way of support for the premise of David Lloyd's Irish Culture and Colonial Modernity, I800-200o: The Transformation of Oral Space, which opens with a series of provocative claims about the status of orality in Irish culture. Lloyd writes: "With the remarkable consistency that suggests that they are distorted forms of knowledge, stereotypes of the Irish cluster around the things we do with a single orifice, the mouth" (p. 1). He goes on to argue that the performing, liable mouth figures so prominently in post-Famine Irish culture that "in the case of the Irish, it may be that racial difference is principally determined not by markers like skin colour or facial features that supposedly offer themselves to immediate visual recognition, but by the largely non-visual signifiers of orality" (p. 2). In short: "The mouth is the privileged corporeal signifier of Irish racial and cultural difference" (p. 3). This is an engaging departure for what proves to be an incisive, compelling, and topically broad book about the role of orality in Ireland, not just as a marker of identity, but more specifically as a tool of countermodern resistance.

Orality, as Lloyd frames it, encompasses more than just speech. It indicates a whole range of oral practices including speech, of course, but also eating, drinking, gossiping, singing, keening, as well as certain forms of writing that either create the collective ethic of an oral community or are composed of stylistic features that "insist" on the "physical presence" of the oral. Recognizing the apparent paradox of the term, Lloyd refers to these as "oral texts" (p. 214). He cites much of Samuel Beckett's writing in this regard, and though he does not mention it specifically, one would surely include James Joyce's Finnegans Wake in the category of "oral text."

But the book's concern is not with orality per se. It is with the specific spatial formations that sustain orality as a practice of resistance. The argument goes something like this: since orality draws on a premodern ethic (following Walter Ong and others), it is in many ways recalcitrant to coloniality, modernity, and a range of statist "civilizing" practices that serve the interests of economic rationalization and cultural homogenization. But unlike Ong, who locates orality purely within a temporal-historicist frame, in which the oral predates the literary, Lloyd is concerned with the spatial dimension of orality in modern times. The "oral spaces" Lloyd describes are, themselves, products of modernity in which the premodern oral impulse "lives on," albeit in something of a transformed version of its former self (p. 219).

The chapters are organized in a largely chronological order and focus on the following topics: the "oral space" that sustained and was 
sustained by the farming practices associated with the potato in the years leading up to, during, and just after the Famine $\left(1845^{-5} 5^{1)}\right.$; the performance of keening (an oral form of mourning for the dead); public drinking practices at the turn of the twentieth century, examined through Joyce's short story "Counterparts"; the creation of "oral space" among Republican political prisoners in Northern Ireland's Maze Prison during the mid 1970s and early 1980s; an analysis of written texts by Charles Baudelaire and Bobby Sands; and a consideration of Beckett's little-discussed short novel How It Is, which Lloyd reads within the frame of Immanuel Kant's "pathological subject."

The book's chapter on the potato is one of its finest, earlier versions of which were published in Nineteenth-Century Contexts, 29 (2007), and in Nineteenth-Century Worlds: Global Formations Past and Present, ed. Keith Hanley and Greg Kucich (London: Routledge, 2008). Prior to the Famine, the potato served two broad functions in Ireland: first, because it could be grown effectively on a small plot of marginal land with poor soil, a family could live off the product of a one-acre plot for an entire year; second, the way in which the potato was farmed, through a combination of communal and individual plots in close proximity to one another, sustained a complex form of social life rooted in oral practices. But outside Ireland, the potato was a symbol of Irish degeneracy and pestilence, particularly in the mainstream British press and discourse of colonization. This discursive rendering of the potato is not unrelated to the fact that, as a marketable commodity, it was not well suited to colonial capitalism. For one thing, the way in which the potato was grown-on small, seemingly irrationally organized plots of land-frustrated colonial attempts to consolidate smaller plots into larger holdings. For another, the potato, unlike corn, for example, was not conducive to storage or travel over long distances. It was a crop "confined to its locality" (p. 37), and it presented something of a challenge to the colonial-capitalist enterprise. The oral space associated with the cultivation and consumption of the potato, thus, provided a site of countermodern and countercolonial recalcitrance.

The other standout chapters in the book are the next two, which address the oral spaces of the public house and Northern Ireland's Maze Prison, respectively. Earlier versions of these chapters have also been published previously in Semicolonial Joyce, ed. Derek Attridge and Marjorie Howes (Cambridge: Cambridge Univ. Press, 2000), and in Hunger Strike: Reflections on the I98 I Hunger Strike, ed. Danny Morrison (Dingle: Brandon Books, 20o6). Lloyd argues that as the physical space of the pub is marked by orality (drinking, singing, storytelling, 
gossiping, and conversing in all its forms), it is also a space of countermodernity in that it provides a home for specific social performances that undermine the market-based rhythms of labor, hierarchy, and discipline (time spent drinking represents time away from work). Moreover, the social performances of drinking threaten the logic of accumulation, promote psychic dependence, give rise to rumor, sedition, and dissent, and ultimately, defy the ethical formation of the modern subject. And yet, despite the fact that drinking practices are imbued with a countermodern ethos of orality, the pub itself is framed and contained by modernity. In its mandated opening and closing times, rules regarding what can or cannot be served, who is allowed in and who should be kept out, the pub is a site of regulation and control, a space in which modernity undeniably extends its disciplinary reach. The oral performances that take place within the public house, then, are not simply the reside of a premodern era; rather they are "the recalcitrant effects of modernity itself" and the "non-modern practices of oral culture transformed into the countermodern practices of oral space in modern times" (pp. 101-2).

Likewise, in the chapter on the H-Block Republican prisoners, Lloyd argues that the physical construction of the Maze Prison-small cells located side-by-side along straight corridors-enabled a lively oral culture, especially at night, when prisoners sang, recited stories from memory, engaged in political debates, or learned Irish together. The communal ethic these acts of orality helped forge challenged the spatial logic of the prison itself and its aim of isolation through "silence and separation" (p. 149). Like public drinking practices, these acts of orality were not just premodern holdovers waiting on development; rather, they were the products of a present moment constituted by the physical space of the prison. Insofar as these acts of orality created a collective ethic against the disciplinary regime of the prison, they served to construct alternative social imaginaries "in the present and for the future" (p. $4^{8)}$.

Lloyd ends Irish Culture and Colonial Modernity with two chapters on three literary texts: Charles Baudelaire's sonnet "A Une Passante"; Bobby Sands's prison ballad "The Crime of Castlereagh"; and Samuel Beckett's novel—his "most desolate, unrelievedly abysmal text" — How It Is (p. 198). Though textual in form, Lloyd makes the case for their inclusion in a book on orality, noting that these texts were either born of an oral space (in the case of Sands's prison ballad, which he wrote while incarcerated in the Maze Prison) or arguing that they feature certain oral characteristics of language in their formal construction, as he claims for Beckett's How It is, which "everywhere insists on its 
materiality, on its physical presence and texture as breath" (p. 214). Framing these texts as recalcitrant to the modern logic of rationality, homogeneity, and surveillance allows Lloyd to discuss several sources of tyranny within the contemporary scene of postmodernity: the maximum security state, the rise of austerity programs, and "the terrifying prospect of a world subjected to a single economic and political model" (p. 218). He even makes reference to Barack Obama and the collapse of the Celtic Tiger. This unexpected shift, for this reader anyway, into a critique of the contemporary economic and political logic of postmodernity is a fitting conclusion for a book as broad as this one.

Few authors have written as profoundly about Irish cultural identity within the interrelated contexts of (post)modernity and (post) coloniality as David Lloyd. His second book, for instance, Anomalous States: Irish Writing and the Post-Colonial Moment (Durham, N.C.: Duke Univ. Press, 1993), remains, twenty years after its publication, one of the most important books at the intersection of Irish literary and postcolonial studies. Irish Culture and Colonial Modernity makes a worthy companion.

Matthew Spangler San José State University

GeOFFREy SANBORn, Whipscars and Tattoos: "The Last of the Mohicans," "Moby-Dick," and the Maori. New York: Oxford University Press, 2011. Pp. xviii +184 . \$49.95.

Geoffrey Sanborn's Whipscars and Tattoos: "The Last of the Mohicans," "Moby-Dick," and the Maori represents the formative potential of the very best kind of traditional literary historicism. Re-contextualizing James Fenimore Cooper's The Last of the Mohicans (1826) and Herman Melville's Moby-Dick (1852) with antebellum accounts of Maori rangatira (chiefs), Sanborn offers new historical perspectives on the social fantasies mobilized in "two of the most important novels in American literary history" (p. 11). Building on his first monograph, The Sign of the Cannibal: Melville and the Making of a Postcolonial Reader (Durham, N.C.: Duke Univ. Press, 1998), Sanborn uses a consideration of Maori cross-cultural encounters to drastically adjust critical perspectives on Magua and Queequeg. These reassessments hold much import for scholars of antebellum America, but 